\title{
Komunikasi Persuasif Agen Asuransi Dalam Merekrut Calon Agen ( Studi Kasus Tentang Perekrutan Calon Agen Dalam Meningkatkan Penjualan Polis di Asuransi PT.AXA
}

\author{
Fatimah \\ Program Magister Ilmu Komunikasi \\ Universitas Jayabaya Jakarta \\ Jln. Pulomas Selatan Kav 23 Jakarta Timur \\ Telp: (021) 4700892, Email : mimip.axa@gmail.com
}

\begin{abstract}
Abstrak
Tesis ini dilakukan untuk mengetahui proses komunikasi persuasif yang dilakukan agen dalam mencari agen dan mengetahui model strategi komunikasi persuasif yang dilakukan dalam proses rekrutmen agen. Metode yang digunakan pendekatan studi kasus dan terdapat hubungan signifikan antara komunikasi persuasif agen terhadap proses perekrutan calon agen.Peneliti memberikan intervensi hubungan komunikasi persuasif lebih di tingkatkan oleh agen agar memudahkan dalam pross merekrut calon agen di PT.AXA. Tanggapan perusahaan pun masih positif untuk meningkatkan proses rekrutmen. Perusahaan pun bersedia memberikan pelatihan komunikasi persuasif untuk meningkatkan proses rekrutmen.
\end{abstract}

Kata Kunci :Komunikasi Persuasif, Agen Calon Agen, Perekrutan

\begin{abstract}
This thesis is conducted to find out the persuasive communication process carried out by agents in finding agents and knowing the persuasive communication strategy model carried out in the agency recruitment process. The method used is a case study approach and there is a significant relationship between agent persuasive communication on the recruitment process of prospective agents. Researchers provide interventions in persuasive communication relationships that are increased by agents to facilitate the process of recruiting prospective agents at PT.AXA. The company's response is still positive to improve the recruitment process. The company is also willing to provide persuasive communication training to improve the recruitment process.
\end{abstract}

Keywords: Persuasive Communication, Agent Candidates, Recruitment 


\section{Pendahuluan}

Seiring dengan perkembangan asuransi dan makin meningkatnya kesadaran masyarakat akan pentingnya asuransi di Indonesia, maka pemasaran keagenan akan menambag agen asuransi yang sukses. Mereka terdiri dari latar belakang profesi dan motivasi yang berbedabeda. Agen asuransi bisa dikatakan atau didefinisikan sebagai ujung tombak perusahaan jasa asuransi. Dan status kepgawaian mereka bukan pegawai tetap yang harus digaji setiap bulan oleh perusahaan, gaji mereka dihasilkan berdasarkan angka penjualan polis asuransi. Selain itu sang agen asuransi wajib merekrut calon agen untuk bergabung ke dalam tim nya.

Sistem keagenan saat ini adalah memberikan kesempatan yang luas bagi agen itu sendiri membuat bisnisnya sendiri dan mrncapai posisi tertinggi dalam struktur keagenan.

Didukung dengan strategi dan program yang diciptakan untuk pengembangan bisnis, sejumlah program diciptakan untuk membantu aktiftas dan produktifitas agen seperti seminar marketing dan lain-lain yang disesuaikan dengan kebutuhan itu sendiri.

Jenjang karir sebagai agen asuransi :

1. Finansial Consultan ( FC )

2. Sales Manager ( SM)

3. Asisten District Manajer ( ADM )

4. District Manajer ( DM )

Banyak keuntungan yang didapat oleh agen asuransi dari merekrut calon agen ke dalam timnya misalnya seperti mendapatkan pendapatan tambahan, sarana pengembangan dan percepatan bisnis, mengembangkan pasar baru, pencapaian taret baru kurang mengenal produk yang dijual sehingga melihat keuntungan mencari kurang mengenal produk yang dijual sehingga melihat keuntungan mencari nasabah saja dan di saat nasabah mengetahui produk yang dijual tidak sesuai yang ditawarkan sang agen banyak nasabah mengetahui produk yang dijual tidak sesuai yang ditawarkan sang agen banyak nasabah yang akan complain langsung ke perusahaan asuransi dimana tempat agen bernanung. Dan sebagai perusahaan yang bergerak di bidang jasa maka kepuasan pelanggan menjadi nomer 1 yang diutamakan dikarenakan menyangkut kredibilitas perusahaan itu sendiri sehiingga perusahaan akan menindaklanjuti jika terjadi kerugiaan dipihak nasabah baik material maupun inmaterial. Dan tak sedikit pula agen baru yang akan berhenti di tengah jalan dikarenakan masih banyak masyarakat kurang tertarik mengenai produk investasi seperti asuransi unit link itu sendiri meski asuransi sifatnya mengurangi resiko sakit, atau resiko meninggal cepat. Masih banyak masyarakat Indonesia yang masih kurang mengenal betapa pentingnya asuransi, masyarakat Indonesia yang masih kurang mengenal betapa pentingnya asuransi, masyarakat lebih percaya terhadap produk perbankkan yang mana resiko kehilangan uang akibat menurunkan nilai uang lebih kecil dibandingkan akibat menurunnya uang yang dismpian di perusahaan asuransi dikarenakan saham investasi setiap hari akan naik turun dan perusahaan asuransi dikarenakan saham investasi setiap hari akan naik turun dan perusahaan asuransi dikarenakan saham nasabahnya pada perusahaan investasi yang terpercaya yang dimiliki perusahaan BUMN, namun disisi lain peran sang agenlah yang membuat masyarakat lebih mengenal produk dari asuransi itu sendiri. Sehingga tiddak jarang banyak perusahaan asuransi yang sangat bergantung dari sistem keagenan ini.

Untuk sistem perekrutan tidak dilihat dari jenjang pendidikan seseorang namun lebih dilihat dari pergaulan luas yang mereka miliki. Perekrutan menggunakan komunikasi persuasif bisa dilakukan secara rasional dan secara emosional untuk peningkatan pemahaman mudah dimengerti dan logis bisa diterima sebelum diberikan alasan yang jelas dan wajar. Dengan cara rasional, komponen kognitif pada diri seseorang dapat dipengaruhi. Aspek yang dipengaruhi berupa ide dan konsep. Sedangkan komunikasi persuasif dilakukan secara emosional. Motivasi juga persuasif dengan model atau bujukan seseorang agar mau mengubah opininya atau agar kebutuhan yang diperlukan dapat terpenuhinya dengan menawarkan sesuatu. Dengan motivasi melalui pujianhadiah dan iming tertentu lambat laun yang bersangkutan bisa mengubah opininya.

Di Indonesia AXA beroperasi dengan focus pada asuransi jiwa, asuransi umum dan manajemen asset melaui beragam jalur distribusi.

Ketidakpastian masalah seperti tidak terduganya kematian, sakit, kecelakaan makin membuat tingginya kesadarannya masyarakat Indonesia terhadap pentingnya asuransi. Ini 
dapat dilihat makin bertambahnya perusahaan asuransi baik yang local maupun non local. AXA ditengah persaingan yang makin ketattnya didunia perasuransian menawarkan sejumlah produk asuransi jiwa dan kesehatan yang didukung badan pengelolah keungan nasional PARIBAS. Kemampuan suatu perusahaan meningkat keuntungan tidak lepas dari peranan tenaga pemasar atau agen. Agen AXA dituntut professional dan handal dan mereka dibekali dengan trainng produk serta sertifikasi AAJI agar para agen dapat menjual produk asuransi jiwa maupun kesehatan.

Semakin meningkatnya penjualan tak lepas agen dalam mencari mitra untuk di rekrut agar dapat bergabung di timnya agar makin meningkatnya bonus sehingga pencapain akan target dari perusahaan tercapai. Dalam perekrutan agen-agen baru biasanya dimulai dari orang terdekat seperti keluarga dan teman.

Pencapaian tersebut bukan saja dari segi finansial jika berhasil memperekrrut agen baru namun disisi lain seperti kenaikan jabatan, bonus, itu hanya salah satu hal yang membuat agen ingin terus berjualan sehingga menambah penghasilan dan dapat mencapai target yang diberikan perusahaan asuransi. Namun disisi lain yang terpenting adalah komunikasi persuasif yang lebih mengarah membujuk yakni membangkitkan pengertian dan kesadaran seseorang bahwa apa yang kita sampaikan akan memberikan rupa pendapat atau sikap sehingga ada perubahan. Tetapi perubahaan yang terjadi itu adalah atas kehendak sendiri agar orangorang yang mau direkrut sebagai agen asuransi tertarik menjadi agen, yang mana diketahui menjadi agen bukan hal yang mudah dikarenakan pekerjaan tersebut tidak ada gaji yang pasti tidak seperti PNS dann karyawan, namun untuk pribadi yang sukan tantangan dan penghasilan serta bonus yang tak terbatas maka pekerjaan menjadi agen adalah tantangan tersendiri bagi pribadi yang suka dengan penghasilan tambahan yang tak terbatas.

\section{Metode}

Penelitian konstruktivisme memandang ilmu sosial sebagai analisis sistematis terhadap tindakan sosial yang bermakna melalui pengamatan langsung dan rinci terhadap perilaku sosial dalam situasi keseharian yang alamiah agar mampu memahami dan menafsirkan bagaimana para pelaku sosial yang bersangkutan menciptakan dan memelihara atau mengelola dunia sosial mereka. Praadigma Konstruktivis dipilih karena lebih mewakili cara pandang peneliti untuk menjelaskan kerangka sosial yang terbentuk dalam pola piker masyarakat yang berdasarkan pada common sense yakni bagaimana subyek penelitian memberi makna pada suatu peristiwa atau pengalaman hidupnya. Dalam penelitian ini mengacu pada bagaimana strategi yang digunakan agen dalam merekrut agen baru pada asuransi AXA. Pendekatan yang digunakan adalah induktif, dari hal khusus menuju ke umum dengan membandingkan konsep yang digunakan dengan data yang ada. Dengan paradigm konstruktivis, penelitian menjelaskan bagaimana data yang diperoleh dilapangan melalui wawancara tidak akan pernah sama. Selain itu didalam paradigm konstruktivis, tidak akan terbebas dari nilai yang ada dalam masyarakat ( Poerwandari 2007 : 21). Dalam penelitian ini menggunakan tipe penelitian kualitatif, yang bersifat penafsiran dengan mengunakan pendekatan studi kasus. Dalam penelitian ini membahas secara mendalam untuk lebih mengetahui fenomena seperti opini, kegiatan, perasaan tentang strategi dan kegiatan, perasaan tentang strategi dan kegiatan yang dilakukan untuk merekrut agen baru. Pada intinya studi kasus merupakan pengujian intensif dengan menggunakan berbagai sumber bukti terhadap satu entitas tunggal yang di batasi dalam ruang dan waktu. Tujuan dari studi kasusu adalah meningkatkan pengetahuan mengenai peristiwa komunikasi yang nyata. Penelitian studi kasus memungkinkan untuk mengumpulkan informasi yang detail dan kaya, menyoroti berbagai faktor yang mengatur komunikasi dalam situasi tertentu, melukiskan keunikanya serta mencoba menawarkan pemahaman mendalam yang mempunyai relevan yang luas. Peneitian ini menggunakan single case study yang dirancang untuk melakukan ekspolarasi mendalam mengenai suatu kejadian tertentu dari sbuah fenomena. Penelitian menunjukkan ketertarikan pada sejumlah kecil hal yang dinvestasikan. Dalam penelitian ini menggunakan dua sata yaitu primer dan sekunder. Data primer meliputi strategi dan kegiatan dalam perekrutan agen baru. Menggunakan tehnik pengumpulan data wawancara mendalam dengan informan. Penelitian ini menggunakan studi kasus dengan alasan komunikasikan kasus: 
wawancara mendalam dengan informan. Penelitian ini menggunakan studi kasus dengan alasan komunikasikan kasus:

1. Susahnya mengajak bergabung menjadi agen dikarenakan pandangan orang terhadap pekerjaan sebagai agen asuransi cenderung negatif.

2. Sulitnya mencari agen yang kompeten.

Tehnik analisis data dilakukan dengan penyederhanaan ke dalam yang lebih muda di baca dan diinterprestasikan. Metode analissi data yang digunakan yaitu kualitatif yaitu empat tahap. Pertama membuat dan melakukan wawancara dengan narasumber serta mengumpulkan data hasil pengamatan observasi dan studi pustaka, kedua mengelompokkan data berdasarkan wawancara dan observasi dihubungan dengan masalah pokok dan tujuan penelitian. Ketiga menganalisis strategi perekrutan yang dijalankan serta keempat membuat kesimpulan. Jadwal Penelitian sekitar bulan 5 bulan yaitu Oktober 2014- Februari 2015 dikantor AXA Jalan Prof. Dr. Satrio Kav 18 Jakarta Selatan.

\section{Hasil dan Pembahasan}

Dalam penelitian ini mengacu bagaimana strategi yang digunakan dalam merekrut calon agen baru.

\section{Proses Komunikasi Persuasif Yang Dilakukan Agen Dalam Proses Rekrutmen Agen Baru}

Komunikasi persuasif yang dikemukan Kenneth e. Anderson yang diterjemahkan Efendy ( 1981:103), maka proses komunikasi antarpribadi dimana agen sebagai komunikator berupaya dengan menggunakan lambanglambang untuk mempengaruhi kognisi calon agen sebagai penerima pesan dengan sengaja dilakukan untuk mengubah sikap atau kegiatan seperti yang diinginkan komunikator yaitu agen. Namun definisi dari ahli diatas belum tentu benar-benar sesuai dengan kenyataan. Seperti yang dilakukan oleh agen yang memandang proses komunikasi persuasif dalam menarik calon agen agar mau menjadi agen asuransi dengan tidak memaksa, membujuk secara verbal dan non verbal melalui bonus yang diberikan perusahaan jika mencapai target serta jenjang karier yang menarik jika menjadi agen ditempatnya bekerja. Secara detail mungkin ada perbedaan dengan agen dalam mencari calon agen dengan pendapat Andreson namun tetap dipandang komunikasi persuasif yang berorientasi pada tujuan tertentu yang sengaja dilakukan komunikator.

Agen mengaku dalam awal pencarian calon agen baru, mereka mencontohkan keberhasilan apa saja yang telah didepat dan kemudahan fasilitas apa saja yang akan diberikan perusahaan AXA. Pada proses perekrutan awal, agen tersebut tidak menggunakan paksaan namun sang agen memberikan pemahaman yang terus menerus dan memotivasi sang calon agen dengan memberikan contoh keberhasilan apa saja yang telah dicapai tersebut.

Berawal dari keyakinan akan efektifinya pembentukan perilaku dan mengajak calon agen dengan cara yang santun dan tidak memaksa maka agen berpikir calon agen baru akan dengan senang hati bergabung di AXA, lain halnya jika dalm perekrutan agen, sang agen terlihat memaksa dan arogan dalm perusasif perekrutan tersebut, hal itu pastilah calon agen baru akan lansgung menolak dan tidak tertearik terhadap ajakan tersebut.

Jika ditinjau dengan prinsip komunikasi pessuasif yang dikemukakan oleh Dedy Jamaludin yang menyatakan bahwa keberhasilan komunikasi persuasif terletak terhadap beberapa aspek yaitu :

1. Prinsip Identifikasi

2. Prinsip Tindakan

3. Prinsip Familiritas dan kepercayaan.

4. Prinsip Kejelasan Situasi

Prinsip identifikasi dan tindakan ini merupakan salah satu metode persuasif non verbal yang paling ampuh yang dilakuakn sang agen dalam mencari calon agen baru. Misal sang agen dapat menceritakan keberhasilan dalam mencapai target yang diberikan AXA dan bonus perjalanan ke luar negeri sehingga sang calon agen akan dapat melihat dan memahami alasan kuat dapat bergabung menjadi agen baru di perusahaan AXA. Untuk prinsip komunikasi familitaritas dan kepercayaan adalah jika dalam proses pencarian calon agen merupakan orang yang sudah dikenal dipercaya seperti teman sekantor atau keluarga sehingga memudahkan dalam penjelasan produk asuransi yang akan dijual sehinnga lancar dalam komunikasi persuasif tersebut. Dan prinsip kejelasan situasi tersebut 
merupakan kegiatan sang agen dalam membantu sang calon agen yang ingin direkrut untuk memahami pekerjaan menjadi agen asuransi serta nasehat yang diperlukan sang calon agen untuk mendapatkan nasabah yang loyalitas sehingga tercapai target perusahaan asuransi.

Dari sekina banyak hal yang membuat seseorang memberikan makna atau definisi terhadap sesuatu adalah interaksi yang dilakukan sang agen.

Interaksi yang dilakukan seseorang akan membantunya memberikan makna pada pada sesuatu. Jika sang agen sukses merekrut sang calon agen dan sang calon agen berkomitmen dan konsisten dalam penjualan polis asuransi sehingga menciptakan keuntungan tersendiri bagi sang agen jika team nya berhasil mencapai target perusahaan. Komunikasi persuasif yang terjadi dalam interaksi sang calon agen yang akan direkrut sendiri akan membantunya memaknai asuransi berdasarkan makna yang dibentuk oleh sang agen. Seperi yang dikemukan oleh Stewart L.Tobbs dan Sylvia Moss bahwa komunikasi adalah proses pembentukan makna diantara dua atau orang atau lebih (Mulyana, 2001 : 69 ). Disini sang calon agen memberikan makna pada proses ajakan menjadi agen asuransi melalui penggunakan simbol persuasif yang selama ini digunakan saat berkomunikasi dan berinteraksi dengan agen yang ingin mengajaknya menjadi agen. Proses komunikasi persuasif yang dilakukan agen asuransi dan sang calon agen dapat dikatakan sebagai usaha sang calon agen dapat dikatakan sebagai usaha sang calon agen dalam menegosiasikan makna melalui pesan-pesan persuasif yang dilakukan sang agen. Sehinnga doharapkan sang calon ahen memaknai dan tertarik untuk bergabung menjadi agen melalui proses komunikasi persuasif antara sang agendan agen perekrut itu sendiri.

Sedikit telah dijelaskan diatas
bagaimana cara sang agen dalam
menyampaikan pesan dalam proses komunikasi
persuasif yang dilakukan sang agen yaitu
dengan memberikan nasehat dan petunjuk
bagaimana manfaat asuransi dan keuntungan
jika menjadi agen asuransi. Selain dengan
menyampaikan pesan verbal dan membujuk
serta memotivasi sang calon agen, agen yang
merekrut sang calon agen juga menggunakan

metode lain yakni memberikan contoh merekrut nasabah dan produk asuransi apa saja yang mudah yang ditawarkan saat ini.

Menurut sang agen jika sangcalon agen dipaksakan maka akan mempersempit keingginan sang calon agen dalam menjual dan menapaki jenjang karier diagensi asuransi. Namun di yakini bahwa semua upaya yang dilakukan sang agen dalam proses rekrutmen ini tanpa paksaan sebagai proses awal. Upaya sang agen dalam merekrut sang calon agen dilakukan dengan komunikasi persuasif karena sang agen yakin hanya dengan cara ini usahanya dalam proses pencarian calon agen asuransi akan berhasil. Di era jaman seperti ini pekerjaan sambilan memang kurang diminati kecuali bagi mereka mengerti keuntungan yang akan didapat jika menjadi agen asuransi di AXA.

Perspektif interaksi simbolik yang mencoba memahami perilaku seseorang berdasarkan sudut pandang subyek yang diteliti menjadi agen asuransi. Respon yang sang calon agen berikan pada upaya yang diberikan sang agen dalam proses rekrutmen tersebut memandang bagaimana sang agen itu memandang pekerjaan menjual produk tersebut jika memandang bagaimana sang agen ia memandang pekerjaan menjual produk asuransi tidaklah namun apabila dilihat dari bonus yang cukup besar dan fasilitas lain inilah yang membuat sang calon agen akan tertarik menjadi agen asuransi, dikarenakan pekerjaan menjadi agen adalah pekerjaan yang sangat susah dilapangan akan sering bertemu dengan banyak penolakan. Dikarenakan saat menjadi calon agen sebaiknya disiapkan mental yang kuat dan hanya bonus dan pencapaian karir yang bagus apabila agen berhasil mendapatkan nasabah.

Seperti yang kita ketahui bahwa seseorang akan mempertimbangkan dan memperhitungkan apa yang sedang dilakukannyanya, sang calon agen akan secara sadar atau tidak disadarinya akan mempertimbangkan bahwa menjadi agen adalah pekerjaan yang menguntungkan baik dari segi waktu, pekerjaan menjadi agen dapat dilakukan oleh kebanyakan ibu rumah tangga yang tidak dapat bekerja dikantoran terkait kesibukan menguurus nak, pilihan menjadi agen asuransi adalah pekerjaan yang menguntungkan dilihat dari segi waktu dan segi pendapatan. Selain ibu rumah tangga, mahasiswa juga dapat mengeluti profesi ini 
terkait pekertaaj menjadi asuransi tidak memerlukan datang kekantor seperti karyawan -karyawan yang bekerja dari senin -jumat dari jam 8.00 - 17.00 .

\section{Kesimpulan}

Dalam penelitian yang telah dilakukan beberapa bulan oleh peneliti akhirnya beberapa kesimpulan dapat ditarik berdasarkan fakta dan realita memalui wawancara atau proses perekrutan calon agen, kesimpukan itu antara lain:

Peneliti menyimpulkan proses komunikasi antara agen dan calon agen dalam proses rekrutmen dilakukan secara intensif.

Peneliti menyimpulkan bahwa upaya dalam menyampaikan pesan dan ajakan kepada calon agen berdasarkan kebutuhan rekrutmn dan pencapaian dimana sang agen memberikan calon prestasi yang telah diraih dalam proses penjualan kepada nasabah.

\section{Saran}

Adapun saran peneliti kepada agen, peneliti menyarankan :

Dalam komunikasi persuasif yang dilakukan agen dengan calon agen sebaiknya menitik beratkan bagaimana mencari nasabah, bagaimana menjual yang baik atau kiat apa saja agar kurir sang calon lebih meningkat.

Sang agen mengaku upaya dalam proses rekrutmen bagi calon agen belum maksimal peneliti menyarankan agarlebih banyak bertemu orang baru, jangan merekrut keluarga dan rekan kerja yang ditawarkan namun jaringan baru yang wajib di prospek sehingga menambah orang tertarik menjadi agen.

Bagi sang agen agarlebih ditekuni pekerjaan menjadi seorang agen dan lebih giat mencari agen baru, dikarenakan asuransi adalah jasa keuangan yang menguntungkan.

\section{Daftar Pustaka}

Efendi, OU, Ilmu Teori dan Filsafat Komunikasi. Bandung :PT. Citra Aditya Bakti, 2003.

Karlinger, Fred. N. Tehnik dan Ilmu Pengetahuan : PT Gadjah Mada University Press. 2010.

Mulyana, Dedy, Ilmu Komunikasi Suatu Pengantar.Bandung : $\quad$ PT Remaja Rosdakarya.2007.

Rakhmat, Jalaluddin, Psikologi Komunikasi : Bandung: PT. Remaja Rosdakarya. 1998.

Rubino, Joe, 7 Langkah Mencapai Kebebasan Finansial Lewat Pemasaran Jaringan. Jakarta: Gramedia Pustaka. 2013.

Riswandi, Psikologi Komunikasi. Bandung : PT Rremaja Rosdakarya. 2013.

Wade, Carol, Psikologi 2. Jakarta. PT.Erlangga.2009. 